Article

\title{
Information Flow and Health Policy Literacy: The Role of the Media
}

\author{
Gregor Wolbring $^{1, *}$, Verlyn Leopatra ${ }^{2}$ and Sophya Yumakulov ${ }^{2}$ \\ 1 Department of Community Health Sciences, University of Calgary, Calgary, \\ Alberta T2N4N1, Canada \\ 2 Faculty of Medicine, University of Calgary, Calgary, Alberta T2N4N1, Canada; \\ E-Mails: vgsleopa@ucalgary.ca (V.L.); sophya.yumakulov@gmail.com (S.Y.)
}

* Author to whom correspondence should be addressed; E-Mail: gwolbrin@ucalgary.ca; Tel.: +1-403-210-7083; Fax: +1-403-220-6494.

Received: 6 April 2012; in revised form: 19 July 2012 / Accepted: 23 August 2012 /

Published: 31 August 2012

\begin{abstract}
People increasingly can and want to obtain and generate health information themselves. With the increasing do-it-yourself sentiment comes also the desire to be more involved in one's health care decisions. Patient driven health-care and health research models are emerging; terms such as participatory medicine and quantified-self are visible increasingly. Given the health consumer's desire to be more involved in health data generation and health care decision making processes the authors submit that it is important to be health policy literate, to understanding how health policies are developed, what themes are discussed among health policy researchers and policy makers, to understand how ones demands would be discussed within health policy discourses. The public increasingly obtains their knowledge through the internet by searching web browsers for keywords. Question is whether the "health consumer" to come has knowledge of key terms defining key health policy discourses which would enable them to perform targeted searches for health policy literature relevant to their situation. The authors found that key health policy terms are virtually absent from printed and online news media which begs the question how the "health consumer" might learn about key health policy terms needed for web based searches that would allow the "health consumer" to access health policy discourses relevant to them.
\end{abstract}

Keywords: health policy literacy; media; knowledge transfer; health information 


\section{Introduction}

How we envision health care constantly changes. Advances in science and technology including health information technology are one dynamic influencing visions and reality of various aspects of health care including the facet of who generates, conveys and acts on health information. In recent times one can observe the move towards a more active role of the "patient", the emergence of the health consumer [1-11], a move towards participatory medicine [12,13], quantified self-tracking [14,15] and patient driven health-care models [14] which among others change the dynamic of who generates, conveys and acts upon health information. The extent to which health consumers are able to act upon information and actively participate will depend on their level of health policy literacy. According to Schoole, "Stakeholders required a certain level of policy literacy to effectively participate in the policy process and the model within which policy development unfolded.” [16] According to Cross, Mungadi and Rouhani, Schoole perceives as a "lack of policy literacy", the lack of understanding of the complexities entailed in the process of development, negotiation, adoption and implementation of policy in a particular context [17]. According to Malone, "Basic health policy literacy means having some understanding of the ways policy issues have been shaped by larger social forces, and how they have been addressed in the past.” [18]

The authors submit that health policy literacy includes among others (a) the understanding of how policies are developed and their social embeddedness; (b) the understanding of the history of presented arguments in a given health policy discourse and the consequences flowing from contemporary arguments used; (c) how policies and their discourses might be impacted by emerging social and scientific and technological developments [19-28].

The authors submit that there is a need for an increased health policy literacy among health consumers in order to be able to contribute in a meaningful way to the shaping of health policies given constantly changing laws, policies and actions frameworks for health care deliverance and public health [29-31], changing threats to health and wellbeing and even changes to the very meaning of health [31].

Many academic journals have health policy sections such as the American Journal of Public Health but how does the public achieve health policy literacy and health policy discourse literacy? Given that the public, health consumers included, obtains information increasingly online by inputting keyword queries into search engines, the authors submit that the public must as one skill have the knowledge of keywords that define various health policy discourses. Searching with the right keywords opens the gate to obtaining health policy and health policy discourse information, which is a prerequisite to health policy literacy.

Diffusion of knowledge through printed media is seen for a long time as an essential fabric of society enabling participation in society [32-38].

The authors submit that media have a vital role to play in generating keyword recognition knowledge for the public The authors present in this paper the visibility of key health policy terms in news media, medical and health journals. The authors found that key health policy terms were virtually absent from printed and online news media which begs the question how the public develops the knowledge of key search terms that allows them to access key health policy discourses. 


\section{Results}

Although there are health policy terms such as health insurance, well-being and health care reform that are mentioned more in the news media group than in the medical and public health journal group or health journal database group the authors found that the frequency of most key health policy terms such as health economics, health ethics, determinants of health, burden of disease, social wellbeing, tele-health, e-health, disability adjusted life years, health technology, health technology assessment and evidence based medicine is $10-100$ fold lower in the news media group versus the medical and public health journal group and health journal databases group (Table 1).

Table 1. Frequency of health policy terms covering different areas in different types of publications.

\begin{tabular}{|c|c|c|c|c|c|c|}
\hline \multirow[t]{2}{*}{ Keywords } & \multicolumn{2}{|c|}{$\begin{array}{c}\text { News media (New York } \\
\text { Times; CNN; Times, UK) }\end{array}$} & \multicolumn{2}{|c|}{$\begin{array}{l}\text { British Medical Journal } \\
\text { (BMJ), AJPH and Lancet }\end{array}$} & \multicolumn{2}{|c|}{ Health journal databases } \\
\hline & $\circ$ & $\%$ of "health" & $\circ$ & $\%$ of "health" & $\circ$ & \% of "health" \\
\hline Health & 1185982 & 100.000 & 246401 & 100.000 & 4652279 & 100.000 \\
\hline Patient & 346258 & 29.196 & 247983 & 100,642 & 5324061 & 114.440 \\
\hline Healthcare & 130636 & 11.015 & 34829 & 14.135 & 1158108 & 24.893 \\
\hline Public health & 70092 & 5.910 & 106319 & 43.148 & 764042 & 16.423 \\
\hline Health economics & 205 & 0.017 & 4187 & 1.6992 & 21513 & 0.462 \\
\hline Health client & 47 & 0.004 & 8 & 0.00325 & 245 & 0.005 \\
\hline Health ethics & 32 & 0.003 & 533 & 0.216 & 1710 & 0.037 \\
\hline $\begin{array}{l}\text { Determinants of } \\
\text { health }\end{array}$ & 20 & 0.002 & 642 & 0.2605 & 6909 & 0.149 \\
\hline Burden of disease & 70 & 0.006 & 1381 & 0.560 & 10902 & 0.234 \\
\hline Social well being & 502 & 0.042 & 361 & 0.1465 & 4320 & 0.093 \\
\hline Telehealth & 25 & 0.002 & 32 & 0.01299 & 6029 & 0.130 \\
\hline e-health & 39 & 0.003 & 362 & 0.1469 & 4850 & 0.104 \\
\hline $\begin{array}{c}\text { Disability adjusted } \\
\text { life years } \\
\end{array}$ & 72 & 0.006 & 390 & 0.15828 & 1785 & 0.038 \\
\hline Health technology & 731 & 0.062 & 802 & 0.3254 & 11317 & 0.243 \\
\hline $\begin{array}{c}\text { Health technology } \\
\text { assessment }\end{array}$ & 25 & 0.002 & 579 & 0.2349 & 6303 & 0.135 \\
\hline $\begin{array}{l}\text { Evidence based } \\
\text { medicine }\end{array}$ & 125 & 0.011 & 2126 & 0.8628 & 58710 & 1.262 \\
\hline
\end{tabular}

If one assumes that health policy terms are first used in health related academic discourses it might be understandable that newer terms such as tele-health and e-health are less visible in the public media as it takes time for terms to diffuse from one discourse to another. However, most terms are around for some time in the health policy and research literature. Interestingly for some newer developments certain terms with health policy implications are invisible in all three groups. Searching the New York Times for terms such as "participatory medicine" or "quantified self" or "quantifying self", or "self quantified" do not generate any hits. The phrase "user generated data" only generates 15 hits. All these terms do not generate hits in the American Journal of Public Health, Lancet or the British Medical Journal and none to below five hits in the different health databases searched for data for this paper. These terms are available in media 
outlets that cover cutting edge developments in a foresight manner such as TED talks. This suggests that it is not only the non-academic media that has problems with introducing their readers to cutting edge developments with health policy implications but that the academic media also has problems. Tables 2-4 give the hit results in more detail for the individual members of the different publication groups.

Table 2. Frequency of health policy terms covering different areas in British Medical Journal (BMJ), AJPH and Lancet.

\begin{tabular}{|c|c|c|c|c|c|c|c|c|}
\hline \multirow[b]{2}{*}{ Keywords } & \multicolumn{2}{|c|}{ BMJ } & \multicolumn{2}{|c|}{ Lancet } & \multicolumn{2}{|c|}{ AJPH } & \multicolumn{2}{|c|}{ All Together } \\
\hline & $\begin{array}{c}\text { All } \\
\text { fields }\end{array}$ & $\begin{array}{c}\text { \% of } \\
\text { "health" }\end{array}$ & $\begin{array}{c}\text { All } \\
\text { fields }\end{array}$ & $\begin{array}{c}\text { \% of } \\
\text { "health" }\end{array}$ & $\begin{array}{c}\text { All } \\
\text { fields }\end{array}$ & $\begin{array}{c}\text { \% of } \\
\text { "health" }\end{array}$ & & $\begin{array}{c}\% \text { of } \\
\text { "health" }\end{array}$ \\
\hline Health & 165099 & 100.00 & 44724 & 100.00 & 36578 & 100.00 & 246401 & 100.000 \\
\hline Patient & 232592 & 140.88 & 1536 & 3.43 & 13855 & 37.878 & 247983 & 100,642 \\
\hline Health care & 19506 & 11.81 & 7483 & 16.73 & 7840 & 21.434 & 34829 & 14.135 \\
\hline Health economics & 3502 & 2.12 & 253 & 0.57 & 432 & 1.181 & 4187 & 1.6992 \\
\hline Health client & 0 & 0.00 & 0 & 0.00 & 8 & 0.022 & 8 & 0.00325 \\
\hline Health reform & 272 & 0.16 & 150 & 0.34 & 258 & 0.705 & 680 & 0.2764 \\
\hline Health ethics & 256 & 0.16 & 19 & 0.04 & 116 & 0.317 & 533 & 0.216 \\
\hline $\begin{array}{c}\text { "Determinants of } \\
\text { health" }\end{array}$ & 290 & 0.18 & 236 & 0.53 & 410 & 1.121 & 642 & 0.2605 \\
\hline Health systems & 1047 & 0.63 & 1146 & 2.56 & 737 & 2.015 & 2930 & 1.189 \\
\hline Public health & 47457 & 28.74 & 16510 & 36.92 & 34728 & 94.942 & 106319 & 43.148 \\
\hline Health Insurance & 5189 & 3.14 & 945 & 2.11 & 2681 & 7.330 & 8815 & 3.577 \\
\hline Health care reform & 421 & 0.25 & 134 & 0.30 & 341 & 0.932 & 896 & 0.3636 \\
\hline Burden of disease & 442 & 0.27 & 689 & 1.54 & 250 & 0.683 & 1381 & 0.560 \\
\hline Global health & 606 & 0.37 & 1158 & 2.59 & 540 & 1.476 & 2304 & 0.935 \\
\hline health research & 2237 & 1.35 & 1426 & 3.19 & 1838 & 5.025 & 5501 & 2.232 \\
\hline social health & 191 & 0.12 & 84 & 0.19 & 257 & 0.703 & 532 & 0.2159 \\
\hline Well being & 5244 & 3.18 & 428 & 0.96 & 2565 & 7.012 & 8237 & 3.342 \\
\hline Social well being & 134 & 0.08 & 21 & 0.05 & 206 & 0.563 & 361 & 0.1465 \\
\hline Environmental health & 1223 & 0.74 & 431 & 0.96 & 1963 & 5.367 & 3617 & 1.4679 \\
\hline Medical health & 235 & 0.14 & 30 & 0.07 & 437 & 1.195 & 702 & 0.2849 \\
\hline Health services & 17064 & 10.34 & 3363 & 7.52 & 8898 & 24.326 & 29325 & 11.9013 \\
\hline Telehealth & 22 & 0.01 & 5 & 0.01 & 5 & 0.014 & 32 & 0.01299 \\
\hline e-health & 148 & 0.09 & 18 & 0.04 & 196 & 0.536 & 362 & 0.1469 \\
\hline Health policy & 7771 & 4.71 & 1145 & 2.56 & 3075 & 8.407 & 11991 & 4.8664 \\
\hline Health law & 307 & 0.19 & 86 & 0.19 & 855 & 2.337 & 1248 & 0.5064 \\
\hline $\begin{array}{c}\text { Disability adjusted life } \\
\text { years } \\
\end{array}$ & 103 & 0.06 & 238 & 0.53 & 29 & 0.079 & 390 & 0.15828 \\
\hline Health technology & 590 & 0.36 & 172 & 0.38 & 40 & 0.109 & 802 & 0.3254 \\
\hline $\begin{array}{c}\text { Health technology } \\
\text { assessment }\end{array}$ & 450 & 0.27 & 120 & 0.27 & 9 & 0.025 & 579 & 0.2349 \\
\hline $\begin{array}{c}\text { Evidence based } \\
\text { medicine } \\
\end{array}$ & 1551 & 0.94 & 492 & 1.10 & 83 & 0.227 & 2126 & 0.8628 \\
\hline
\end{tabular}


Table 3. Frequency of health policy terms covering different areas in Health Journal bundled in different databases.

\begin{tabular}{|c|c|c|c|c|c|c|c|c|c|c|c|c|}
\hline \multirow[t]{2}{*}{ Keywords } & \multirow{2}{*}{$\begin{array}{c}\text { Canadian } \\
\text { Health } \\
\text { Research } \\
\text { Collection } \\
\text { 1999-today } \\
\text { Title, \% of } \\
\text { "health” } \\
\end{array}$} & \multicolumn{2}{|c|}{$\begin{array}{l}\text { CINAHL } \\
1974-2010\end{array}$} & \multicolumn{2}{|c|}{$\begin{array}{c}\text { AgeLine (AARP) } \\
\text { database } \\
\text { 1978-2010 }\end{array}$} & \multicolumn{2}{|c|}{$\begin{array}{c}\text { Health Source } \\
\text { Consumer Edition } \\
\text { 1984-2010 }\end{array}$} & \multicolumn{2}{|c|}{$\begin{array}{c}\text { Health Source: Nursing } \\
\text { Academic Edition } \\
\text { 1952-2010 }\end{array}$} & \multicolumn{2}{|c|}{$\begin{array}{c}\text { Informa Healthcare } \\
\text { 1918-2010 }\end{array}$} & \multirow{2}{*}{$\begin{array}{c}\text { Pubmed } \\
\text { 1870-2010 } \\
\text { Title, \% of } \\
\text { "health" }\end{array}$} \\
\hline & & $\begin{array}{l}\text { Title, \% of } \\
\text { "health" }\end{array}$ & $\begin{array}{l}\text { Text, \% of } \\
\text { "health" }\end{array}$ & $\begin{array}{l}\text { Title, \% of } \\
\text { "health" }\end{array}$ & $\begin{array}{l}\text { Text, \% of } \\
\text { "health" }\end{array}$ & $\begin{array}{l}\text { Title, \% of } \\
\text { "health" }\end{array}$ & $\begin{array}{l}\text { Text, \% of } \\
\text { "health" }\end{array}$ & $\begin{array}{l}\text { Title, \% of } \\
\text { "health" }\end{array}$ & $\begin{array}{l}\text { Text, \% of } \\
\text { "health" }\end{array}$ & $\begin{array}{l}\text { Title, \% of } \\
\text { "health” }\end{array}$ & $\begin{array}{l}\text { Text, \% of } \\
\text { "health" }\end{array}$ & \\
\hline Patient & 61.815 & 41.279 & 35.133 & 12.524 & 30.294 & 36.502 & 44.308 & 120.528 & 89.075 & 420.981 & 157.947 & 192.941 \\
\hline $\begin{array}{c}\text { Health } \\
\text { Care }\end{array}$ & 70.206 & 19.077 & 22.448 & 23.881 & 32.670 & 15.511 & 20.739 & 17.557 & 29.259 & 16.384 & 22.999 & 22.987 \\
\hline $\begin{array}{c}\text { Health } \\
\text { economics }\end{array}$ & 11.119 & 0.078 & 0.432 & 0.139 & 0.091 & 0.023 & 0.104 & 0.110 & 0.748 & 0.143 & 0.926 & 0.321 \\
\hline Health client & 0.149 & 0.004 & 0.008 & 0.011 & 0.009 & 0.000 & 0.002 & 0.000 & 0.009 & 0.020 & 0.014 & 0.001 \\
\hline Health ethics & 0.872 & 0.043 & 0.040 & 0.000 & 0.006 & 0.053 & 0.029 & 0.065 & 0.088 & 0.000 & 0.059 & 0.017 \\
\hline $\begin{array}{l}\text { "Determinants } \\
\text { of health" }\end{array}$ & 17.616 & 0.171 & 0.175 & 0.128 & 0.170 & 0.045 & 0.120 & 0.153 & 0.395 & 0.041 & 0.051 & 0.000 \\
\hline Health systems & 13.960 & 0.814 & 2.413 & 0.139 & 0.293 & 0.743 & 2.308 & 0.564 & 2.374 & 0.061 & 1.187 & 0.415 \\
\hline Public health & 62.595 & 6.400 & 14.348 & 1.028 & 3.173 & 8.446 & 15.703 & 8.648 & 26.863 & 3.085 & 23.539 & 14.038 \\
\hline $\begin{array}{c}\text { Health } \\
\text { Insurance }\end{array}$ & 15.110 & 1.177 & 1.563 & 2.890 & 8.440 & 1.697 & 4.287 & 1.423 & 4.012 & 0.245 & 2.005 & 2.304 \\
\hline $\begin{array}{l}\text { Health care } \\
\text { reform }\end{array}$ & 7.091 & 0.992 & 1.106 & 0.856 & 2.675 & 1.329 & 1.215 & 1.089 & 1.162 & 0.347 & 0.267 & 1.145 \\
\hline $\begin{array}{c}\text { Burden of } \\
\text { disease } \\
\end{array}$ & 5.235 & 0.072 & 0.176 & 0.021 & 0.065 & 0.098 & 0.125 & 0.153 & 0.573 & 0.204 & 0.941 & 0.112 \\
\hline Global health & 3.174 & 0.399 & 0.316 & 0.086 & 0.095 & 0.495 & 0.294 & 0.666 & 0.787 & 0.020 & 0.608 & 0.223 \\
\hline health research & 29.905 & 0.656 & 1.819 & 0.235 & 0.321 & 0.533 & 1.539 & 0.961 & 3.839 & 0.613 & 4.255 & 1.390 \\
\hline
\end{tabular}


Table 3. Cont

\begin{tabular}{|c|c|c|c|c|c|c|c|c|c|c|c|c|}
\hline \multirow[t]{2}{*}{ Keywords } & \multirow{2}{*}{$\begin{array}{c}\text { Canadian } \\
\text { Health } \\
\text { Research } \\
\text { Collection } \\
\text { 1999-today } \\
\text { Title, \% of } \\
\text { "health" } \\
\end{array}$} & \multicolumn{2}{|c|}{$\begin{array}{l}\text { CINAHL } \\
\text { 1974-2010 }\end{array}$} & \multicolumn{2}{|c|}{$\begin{array}{c}\text { AgeLine (AARP) } \\
\text { database } \\
\text { 1978-2010 }\end{array}$} & \multicolumn{2}{|c|}{$\begin{array}{c}\text { Health Source } \\
\text { Consumer Edition } \\
\text { 1984-2010 }\end{array}$} & \multicolumn{2}{|c|}{$\begin{array}{c}\text { Health Source: Nursing } \\
\text { Academic Edition } \\
\text { 1952-2010 }\end{array}$} & \multicolumn{2}{|c|}{$\begin{array}{c}\text { Informa Healthcare } \\
1918-2010\end{array}$} & \multirow{2}{*}{$\begin{array}{c}\text { Pubmed } \\
\text { 1870-2010 } \\
\text { Title, \% of } \\
\text { "health" }\end{array}$} \\
\hline & & $\begin{array}{c}\text { Title, \% of } \\
\text { "health" }\end{array}$ & $\begin{array}{c}\text { Text, \% of } \\
\text { "health" }\end{array}$ & $\begin{array}{c}\text { Title, \% of } \\
\text { "health" }\end{array}$ & $\begin{array}{l}\text { Text, \% of } \\
\text { "health" }\end{array}$ & $\begin{array}{c}\text { Title, \% of } \\
\text { "health" }\end{array}$ & $\begin{array}{l}\text { Text, \% of } \\
\text { "health" }\end{array}$ & $\begin{array}{c}\text { Title, \% of } \\
\text { "health” }\end{array}$ & $\begin{array}{l}\text { Text, \% of } \\
\text { "health" }\end{array}$ & $\begin{array}{c}\text { Title, \% of } \\
\text { "health" }\end{array}$ & $\begin{array}{l}\text { Text, \% of } \\
\text { "health" }\end{array}$ & \\
\hline Well being & 8.261 & 1.853 & 3.215 & 14.301 & 40.604 & 0.616 & 3.335 & 2.087 & 5.827 & 7.947 & 169.410 & 1.429 \\
\hline $\begin{array}{c}\text { Social well } \\
\text { being }\end{array}$ & 0.575 & 0.014 & 0.094 & 0.054 & 0.321 & 0.000 & 0.051 & 0.013 & 0.206 & 0.041 & 0.333 & 0.033 \\
\hline $\begin{array}{l}\text { Environmental } \\
\text { health }\end{array}$ & 11.027 & 0.593 & 1.018 & 0.021 & 0.065 & 1.269 & 4.351 & 1.129 & 3.667 & 0.388 & 2.903 & 1.884 \\
\hline Medical health & 4.010 & 0.015 & 0.080 & 0.064 & 0.235 & 0.008 & 0.054 & 0.019 & 0.181 & 0.000 & 0.278 & 0.041 \\
\hline Health services & 61.017 & 2.584 & 15.533 & 3.875 & 17.165 & 1.141 & 6.308 & 2.706 & 11.509 & 5.618 & 8.827 & 13.621 \\
\hline Telehealth & 6.757 & 0.420 & 0.219 & 0.235 & 0.110 & 0.150 & 0.118 & 0.145 & 0.119 & 0.082 & 0.094 & 0.050 \\
\hline e-health & 2.877 & 0.176 & 0.124 & 0.021 & 0.015 & 0.135 & 0.143 & 0.095 & 0.192 & 0.061 & 0.317 & 0.038 \\
\hline Health policy & 3.824 & 1.193 & 2.816 & 0.996 & 0.830 & 0.390 & 1.735 & 1.137 & 3.657 & 0.899 & 2.418 & 2.763 \\
\hline $\begin{array}{l}\text { Disability } \\
\text { adjusted life } \\
\text { years }\end{array}$ & 0.446 & 0.009 & 0.028 & 0.000 & 0.002 & 0.008 & 0.026 & 0.018 & 0.101 & 0.020 & 0.163 & 0.026 \\
\hline $\begin{array}{c}\text { Health } \\
\text { Technology }\end{array}$ & 12.437 & 0.182 & 0.313 & 0.021 & 0.032 & 0.023 & 0.094 & 0.090 & 0.359 & 0.204 & 0.577 & 0.112 \\
\hline $\begin{array}{c}\text { Health } \\
\text { Technology } \\
\text { Assessment } \\
\end{array}$ & 10.562 & 0.136 & 0.145 & 0.000 & 0.011 & 0.000 & 0.021 & 0.055 & 0.233 & 0.123 & 0.388 & 0.063 \\
\hline $\begin{array}{l}\text { Evidence based } \\
\text { medicine }\end{array}$ & 1.485 & 0.925 & 0.484 & 0.086 & 0.108 & 0.203 & 0.267 & 0.704 & 1.137 & 1.001 & 1.286 & 2.055 \\
\hline
\end{tabular}


Table 4. Frequency of health policy terms covering different areas in the New York Times; The Times, UK and CNN.

\begin{tabular}{|c|c|c|c|c|}
\hline \multirow[t]{2}{*}{ Keywords } & NYT 1850-today & CNN & $\begin{array}{c}\text { The Times UK } \\
\text { 2003-25 June } 2010\end{array}$ & All \\
\hline & Text, \% of “health” & Text, \% of "health" & Text, \% of “health” & Text, \% of "health" \\
\hline Health & $100=1,069,577$ hits & $100=35,475$ hits & $100=70,620$ hits & $100=1,175,672$ hits \\
\hline Patient & 27.5781 & 27.7237 & 40.9870 & 28.3879 \\
\hline Health care & 11.0241 & 22.2128 & 2.0688 & 10.8238 \\
\hline Health economics & 0.0130 & 0.0226 & 0.0736 & 0.0169 \\
\hline Health client & 0.0042 & 0.0000 & 0.0000 & 0.0038 \\
\hline Health reform & 0.0837 & 0.6399 & 0.1813 & 0.1063 \\
\hline Health ethics & 0.0014 & 0.0395 & 0.0028 & 0.0026 \\
\hline “Determinant of health" & 0.0009 & 0.0028 & 0.0085 & 0.0014 \\
\hline Health systems & 0.7978 & 0.6934 & 0.1813 & 0.7576 \\
\hline Public health & 6.4691 & 5.3305 & 5.2747 & 6.3630 \\
\hline Health Insurance & 3.7356 & 4.5920 & 1.7077 & 3.6396 \\
\hline Health care reform & 0.2667 & 4.6850 & 0.0496 & 0.3870 \\
\hline Burden of disease & 0.0046 & 0.0113 & 0.0297 & 0.0063 \\
\hline Global health & 0.0514 & 0.2791 & 0.1742 & 0.0657 \\
\hline health research & 0.3336 & 0.2509 & 0.3653 & 0.3330 \\
\hline social health & 0.0609 & 0.0592 & 0.0864 & 0.0623 \\
\hline Well being & 2.9700 & 0.0000 & 1.5718 & 2.7964 \\
\hline Social well being & 0.0463 & 0.0000 & 0.0099 & 0.0427 \\
\hline Environmental health & 0.2395 & 0.3242 & 0.8553 & 0.2791 \\
\hline Medical health & 0.1582 & 0.5666 & 0.0453 & 0.1637 \\
\hline Health services & 3.9714 & 0.8795 & 1.8253 & 3.7492 \\
\hline Telehealth & 0.0009 & 0.0282 & 0.0071 & 0.0021 \\
\hline e-health & 0.0205 & 0.0310 & 0.0212 & 0.0208 \\
\hline Health policy & 0.4148 & 0.2734 & 0.5537 & 0.4189 \\
\hline Health law & 0.2050 & 0.0479 & 0.0850 & 0.1931 \\
\hline $\begin{array}{c}\text { Disability adjusted life } \\
\text { years } \\
\end{array}$ & 0.0001 & 0.2001 & 0.0000 & 0.0061 \\
\hline Health technology & 0.0653 & 0.0282 & 0.0269 & 0.0618 \\
\hline $\begin{array}{c}\text { Health technology } \\
\text { assessment }\end{array}$ & 0.0008 & 0.0282 & 0.0085 & 0.0021 \\
\hline Evidence based medicine & 0.0065 & 0.0000 & 0.0637 & 0.0098 \\
\hline
\end{tabular}

As for the difference between the British Medical Journal, Lancet and the American Journal for Public Health (medical and public health journal group, (Table 2)), the BMJ has at least double the hits for the terms patient and health economics; Lancet leads the hits for the terms health systems, burden of disease, disability adjusted life years and global health whereas the American Journal of Public Health leads in 17 other terms. However the gap between position one and two in counts for a given term never exceeds the limit of 5-times less. The results between different health journal databases (Table 3) generated roughly the same hit frequency pattern as evident in AJPH, BMJ and Lancet. 
As for the difference between the NYT, CNN and the Times (UK) (results for the News Media, Table 4) they show remarkable similar percentages for most terms with only a few being more pronounced in one source over the others. Even more remarkable all of them have a very low level to no hits for the key health policy areas terms health economics, health ethics, determinants of health, burden of disease, social well-being, tele-health, e-health, disability adjusted life years, health technology, health technology assessment and evidence based medicine. Indeed if we compare the average of these terms in the media with the hit frequency in for example the AJPH one finds a 30-fold higher frequency count in the AJPH for the term burden of disease; an at least 50-fold higher frequency count in the AJPH for the term health economics, health ethics and more than a 100-fold higher frequency count in AJPH for the term disability adjusted life years, health technology, health technology assessment and evidence based medicine (in relation to the term health used in all the sources).

\section{Experimental Section}

The authors performed a frequency analysis of health policy discourse defining terms such as health economics, health reform, health ethics, determinants of health, health systems, health insurance, health care reform, burden of disease, global health, social health, well-being, social well-being, environmental health, medical health, health services, tele-health, e-health, health law, disability adjusted life years, health technology, health technology assessment, evidence based medicine appearing in three distinct groups of publications. (a) Newspapers and online media (New York Times from 1850 to today; CNN from 1980 to today; The Times UK from 2003 to 2010); (b) Medical and Public health journals (British Medical Journal from 1840 to today; the Lancet from 1840 to today; the American Journal for Public Health from 1911 to today) and (c) various academic databases covering health literature (Canadian Health Research Collection 1999-today; CINAHL 1974-2010; AgeLine (AARP) database 1978-2010; Health Source Consumer Edition 1984-2010; Health Source: Nursing Academic Edition 1952-2010; Informa Healthcare 1918-2010 and Pubmed). The New York Times archives were systematically searched using (a) the ProQuest search engine (provided by the University of Calgary) for articles from 1851 to 2006 and (b) the archive search engine on the New York Times website for articles from 2006 to August 16, 2010). The NYT was searched for various health policy keywords, first as a full text search, and then as a title search (if the text-search generated more than 300 hits). For CNN, British Medical Journal, American Journal of Public Health and Times (UK) the archive search engines on their respective websites were used. Health Journal databases were searched through the University of Calgary databases provided. The search was performed July-August 2010.

Limitation: The health policy discourse defining terms used in this paper were generated by asking three health policy scholars what keywords would come to their minds. The list we used is not an objective or exhaustive one; for a given health topic different health policy terms might be looked at $[39,40]$. Nevertheless, the terms given by the three health policy scholars reflect terms used frequently in health policy discourses. 


\section{Discussion}

So far little effort goes into developing health policy literacy of stakeholders. Although health consumer groups are seen as increasingly getting involved in health policy processes [41] it is less clear how much knowledge individuals of such groups have in regards to health policy discourses; no measure for health policy literacy exists. The Government of Canada and Canada's voluntary sector, announced in June 2000 a partnership with 200 national voluntary health organizations on health policy and program development [42], however it is not clear to date what the impact has been.

"Mass media agendas and health communication objectives can be authoritative allies or forceful foes when it comes to supplying the public with accurate and timely health information.” [43] Media are seen to influence public health policies and the behavior of the health consumer [44-48]. However problems are identified in the role mass media play [43,49,50]. An article by Gasher et al. illustrates that media tend to cover narrow scope angles over broad ones and the article gives various reasons as to why this preference in reporting takes place [51]. That the keywords from health policy discourses are not diffusing into media sources can be seen as one problem of how media report on health issues. Not giving the people the tools to be health policy literate keeps the power within the media to shape discourses. We submit that the lack of visibility of key terms used in health policy discourses within media sources constitutes a breach of the role media are supposed to play and hinders the democratization of the healthcare discourse. Given that health consumers increasingly might not want to influence the system through "their" health consumer group but rather want to directly influence the system, a higher health policy literacy of the individual is needed.

People believe that there is a need to create consumer-friendly terminologies reflecting the different ways healthcare consumers express and think about health topics [52,53]. The authors submit that this is only one needed direction. Keyword literacy of health consumers also has to exist in order to be able to find various health policy discourses. The health consumer needs concise keywords to search the internet and to become health policy literate. Searching terms such as "health policy" leads to too many hits to be really useful. How can one become health policy literate around the discourses of, for example "social determinants of health", if one does not know the term to start with? The key terms have to diffuse from the health policy discourses into the public domain. This would allow people to access many different sources around a given health policy discourse from mass media to open access academic journals increasing their ability to form an opinion based on numerous sources increasing their literacy of evaluating the reporting of any given source on health policy issues.

\section{Conclusions}

If we continue to move down the road of a "health consumer" wanting to shape more and more health care delivery, the authors submit that the "health consumer" becoming more health policy literate is just as important as becoming health information and health literate. As a first step the public has to become familiar with key health policy terms so that they can find discourses linked to various health policy aspects online. That means the media have to familiarize the public with these terms, which so far is not happening. As is the information flow that is not working to produce health policy literate citizens. 


\section{Acknowledgments}

The research was in part supported by an internal University of Calgary, Markin Undergraduate Research Program (USRP) award for Sophya Yumakulov.

\section{References and Notes}

1. Allsop, J.; Jones, K.; Baggott, R. Health consumer groups in the UK: A new social movement? Sociol. Health Illn. 2004, 26, 737-756.

2. Baggott, R.; Jones, K.L. Prevention better than cure? Health consumer and patients' organisations and public health. Soc. Sci. Med. 2011, 73, 530-534.

3. Baggott, R.; Forster, R. Health consumer and patients' organizations in Europe: Towards a comparative analysis. Health Expect. 2008, 11, 85-94.

4. Burgoyne, R.W.; Wolkon, G.H.; Staples, F.; Kline, F.; Powers, M. Which patients respond to a mental-health consumer survey. Am. J. Community Psychol. 1977, 5, 355-360.

5. Elliot, A. My life as a mental health consumer. Isr. J. Psychiatry Relat. Sci. 2010, 47, 195-197.

6. Foster, M.M.; Earl, P.E.; Haines, T.P.; Mitchell, G.K. Unravelling the concept of consumer preference: Implications for health policy and optimal planning in primary care. Health Policy 2010, 97, 105-112.

7. Gallois, C.; Driedger, M.; Sanders, C.; Pisarski, A.; Brabant, M. What is an effective health consumer? A convergent interviewing approach. In Australian Journal of Psychology, Proceedings of The 33rd Annual Meeting of the Society of Australasian Social Psychologists, Auckland, New Zealand, 15-18 April 2004; Taylor \& Francis: Basingstoke, UK, 2004; Volume 56, p. 67.

8. Goncalves, F. A cross country explanation of performance of heath care systems: The consumer point of view using the Euro health consumer index. Econ. Model. 2011, 28, 196-200.

9. Goode, J.; Greatbatch, D.; O’Cathain, A.; Luff, D.; Hanlon, G.; Strangleman, T. Risk and the responsible health consumer: The problematics of entitlement among callers to NHS direct. Crit. Soc. Policy 2004, 24, 210-232.

10. Grace, V.M. The marketing of empowerment and the construction of the health consumer-a critique of health promotion. Int. J. Health Serv. 1991, 21, 329-343.

11. Iriart, C.; Franco, T.; Merhy, E.E. The creation of the health consumer: Challenges on health sector regulation after managed care era. Glob. Health 2011, doi:10.1186/1744-8603-7-2.

12. Dyson, E. Why participatory medicine? J. Particip. Med. 2009. Available online: http://www.jopm.org/opinion/editorials/2009/10/21/why-participatory-medicine/ (accessed on 29 August 2012).

13. Shen, B. Bio-socio-technical underpinnings of participatory medicine. J. Particip. Med. 2009, Available online: http://www.jopm.org/opinion/commentary/2009/10/21/bio-socio-technicalunderpinnings-of-participatory-medicine/ (accessed on 29 August 2012).

14. Swan, M. Emerging patient-driven health care models: An examination of health social networks, consumer personalized medicine and quantified self-tracking. Int. J. Environ. Res. Public Health 2009, 6, 492-525. 
15. Wolf, G. The quantified self. 2010, Available online: http:/www.ted.com/talks/ gary_wolf_the_quantified_self.html (accessed on 12 February 2012).

16. Schoole, T. Key moments in the policy formulation process between 1994 and 2001. 2001, Available online: http://chet.org.za/files/SEHOOLE 2001 Policy formulation process 1994 to 2001.pdf (accessed on 12 February 2012).

17. Cross, M.; Mungadi, R.; Rouhani, S. From policy to practice: Curriculum reform in South African education. Comput. Educ. 2002, 38, 171-187.

18. Malone, R.E. Assessing the policy environment. Policy Polit. Nurs. Pract. 2005, 6, 135-143.

19. Wu, A.D.; Begoray, D.L.; MacDonald, M.; Wharf Higgins, J.; Frankish, J.; Kwan, B.; Fung, W.; Rootman, I. Developing and evaluating a relevant and feasible instrument for measuring health literacy of Canadian high school students. Health Promot. Int. 2010, 25, 444-452.

20. Peerson, A.; Saunders, M. Health literacy revisited: What do we mean and why does it matter? Health Promot. Int. 2009, 24, 285-296.

21. Mogford, E.; Gould, L.; DeVoght, A. Teaching critical health literacy as a means to action on the social determinants of health. Health Promot. Int. 2010, 26, 4-13.

22. Johnson, J.D.; Andrews, J.E. The evolving role of consumers. Clin. Res. Inform. 2012, doi: 10.1007/978-1-84882-448-5_6.

23. Shipman, J.P.; Funk, C.J. Health information literacy. 2007, Available online: https://www.mlanet.org/resources/healthlit/hil_pilot.html (accessed on 12 Febuary 2012).

24. Parker, R.M.; Ratzan, S.C.; Lurie, N. Health literacy: A policy challenge for advancing high-quality health care. Health Aff. 2003, 22, 147-153.

25. Angner, E.; Miller, M.J.; Ray, M.N.; Saag, K.G.; Allison, J.J. Health literacy and happiness: A community-based study. Soc. Indic. Res. 2010, 95, 325-338.

26. Klass, P. When paper is the enemy. Health Aff. 2007, 26, 515-519.

27. Galvin, R.S.; Delbanco, S. Why employers need to rethink how they buy health care. Health Aff. 2005, 24, 1549-1553.

28. U.S. Department of Health and Human Services. Healthy People 2010: Understanding and Improving Health; U.S. Government Printing Office: Washington, DC, USA, 2000.

29. Wolbring, G. The Triangle of Enhancement Medicine, Disabled People, and the Concept of Health: A New Challenge for Hta, Health Research, and Health Policy; Alberta Heritage Foundation for Medical Research, Health Technology Assessment Unit: Edmonton, Alberta, Canada, 2006.

30. Kickbusch, I. Policy Innovation for Health; Springer: Secaucus, NJ, USA, 2009.

31. Wolbring, G. Nanotechnology and the transhumanization of health, medicine, and rehabilitation. In Controversies in Science and Technology Volume 3: From Evolution to Energy; Lee Kleinmann, D., Delborne, J., Cloud-Hansen, K., Handelsman, J., Eds.; Mary Ann Liebert, Inc.: New Rochelle, NY, USA, 2010; pp. 286-298.

32. Nord, D.P. A republican literature: A study of magazine reading and readers in late eighteenth-century New York. Am. Q. 1988, 40, 42-64.

33. Weiner, B.I. The Americanization and periodical publication, 1750-1810. Cercles 2009, 19, 102-113.

34. Weinstock-Netanel, N. Copyright and a democratic civil society. Yale Law J. 1996, 106, 292-392.

35. Burns, A.S.; Beard, V. Banks: Restricted reading, rehabilitation, and prisoners' first amendment rights. J. Law Policy 2007, 15, 1225-1270. 
36. Learned, W.S. The American Public Library and the Diffusion of Knowledge; Carnegie Foundation: New York, NJ, USA, 1924.

37. New York Times. The Civitas reception. New York Times, 2 May 1895, p. 8. Available online: http://query.nytimes.com/mem/archive-free/pdf?res=F10B1FFE3B5D15738DDDAB0894DD40 5B8585F0D3 (accessed on $12^{\text {th }}$ February 2012)

38. The Observer. On the Means of Preserving Public Liberty. New York Times Magazine, January 1790, p. 24.

39. Gilson, L.; Raphaely, N. The terrain of health policy analysis in low and middle income countries: A review of published literature 1994-2007. Health Policy Plan. 2008, 23, 294-307.

40. Scott, R.E.; Jennett, P.A.; Hebert, M.; Rush, B. Telehealth and E-Health Policy Considerations for Alberta; Alberta Health and Wellness: Edmonton, Canada, 2004.

41. Jones, K.; Baggott, R.; Allsop, J. Influencing the national policy process: The role of health consumer groups. Health Expect. 2004, 7, 18-28.

42. Public Health Agency of Canada. Promoting health in Canada. 2001, Available online: http://www.phac-aspc.gc.ca/ph-sp/promo-eng.php (accessed on 12 February 2012).

43. Payne, J.G.; Schulte, S.K. Mass media, public health, and achieving health literacy. J. Health Commun. 2003, 8, 124-125.

44. Otten, A.L. The influence of the mass media on health policy. Health Aff. 1992, 11, 111-118.

45. Sato, H. Agenda setting for smoking control in Japan, 1945-1990: Influence of the mass media on national health policy making. J. Health Commun. 2003, 8, 23-40.

46. Grilli, R.; Ramsay, C.; Minozzi, S. Mass media interventions: Effects on health services utilisation. Cochrane Database Syst. Rev. 2002, doi: 10.1002/14651858.

47. Seale, C. Health and media: An overview. Sociol. Health Illn. 2003, 25, 513-531.

48. Cook, F.L.; Tyler, T.R.; Goetz, E.G.; Gordon, M.T.; Protess, D.; Leff, D.R.; Molotch, H.L. Media and agenda setting: Effects on the public, interest group leaders, policy makers, and policy. Public Opin. Q. 1983, 47, 16-35.

49. Westwood, B.; Westwood, G. Assessment of newspaper reporting of public health and the medical model: A methodological case study. Health Promot. Int. 1999, 14, 53-64.

50. Stryker, J.E. Reporting medical information: Effects of press releases and newsworthiness on medical journal articles' visibility in the news media. Prev. Med. 2002, 35, 519-530.

51. Gasher, M.; Hayes, M.V.; Ross, I.; Hackett, R.A.; Gutstein, D.; Dunn, J.R. Spreading the news: Social determinants of health reportage in Canadian daily newspapers. Can. J. Commun. 2007, 32, 557-574.

52. Cardillo, E.; Serafini, L.; Tamilin, A. A Hybrid methodology for consumer-oriented healthcare knowledge acquisition. Lect. Note. Comput. Sci. 2010, 5943, 38-49.

53. Tripathi, M.; Delano, D.; Lund, B.; Rudolph, L. Engaging patients for health information exchange. Health Aff. 2009, 28, 435-443.

(C) 2012 by the authors; licensee MDPI, Basel, Switzerland. This article is an open access article distributed under the terms and conditions of the Creative Commons Attribution license (http://creativecommons.org/licenses/by/3.0/). 